How to cite this article in bibliographies / References

A Bernárdez-Rodal, G Padilla-Castillo (2018): “Female filmmakers and women’s representation in Spanish commercial cinema (2001-2016)”. Revista Latina de Comunicación Social, 73, pp. 1247 a 1266.

http://www.revistalatinacs.org/073paper/1305/64en.html

DOI: 10.4185/RLCS-2018-1305en

\title{
Female filmmakers and women's representation in Spanish commercial cinema (2001-2016)
}

\author{
Asunción Bernárdez-Rodal $[\underline{\mathrm{CV}}]$ C Department of Journalism and New Media. School of \\ Information Sciences. Feminist Research Institute - Universidad Complutense de Madrid (UCM), \\ Spain - asbernar@ucm.es \\ Graciela Padilla-Castillo [CV] C $\mathcal{C}$ Department of Journalism and New Media. School of \\ Information Sciences. Feminist Research Institute - Universidad Complutense de Madrid (UCM) / \\ Complutense University of Madrid, Spain - gracielp@ucm.es
}

\begin{abstract}
Introduction. This article analyses the representation of women in Spanish commercial cinema: as film directors and as characters. Methods. The study is based on the analysis of primary and secondary sources; the quantitative and diachronic analysis of the highest-grossing Spanish films from 2001 to 2016; the qualitative and descriptive examination of the protagonists, plots and stereotypes of a sample of 26 films. Results. Comedy is the dominant genre. There are 36 male protagonists and 23 female protagonists. The selected films revolve around the wishes of men. Discussion. Men lead the action, are antiheroes, and their sentimentality is underrepresented. Women are companions of men and are in charge of family caretaking and mediation. Conclusions. In Spain, no woman has directed a film that has grossed more than 10 million euros. This situation will not change until representation changes. Commercial cinema can build civic, respectful and human citizens; and not mere consumers, who respond to the commercial interests of the film industry.
\end{abstract}

Keywords

Women; Spanish cinema; commercial cinema; representation; gender stereotypes.

\section{Contents}

1. Introduction. 2. Methods. 3. Results. 4. Discussion. 5. Conclusions. 6. References.

Translation by CA Martínez-Arcos

( $\mathrm{PhD}$ in Communication, University of London) 


\section{Introduction}

The objective of this research is to study the representation of women in Spanish commercial cinema, from two important perspectives: 1) their professional presence as directors, and 2) their representation and stereotyping (both positive and negative) as characters. To achieve solid and profound results, we have examined a fifteen-year period, from 2001 to 2016.

This work is part of a wider project on cultural consumption and digital divide in this area. As an essential step, the research team analysed Spanish cinema in the traditional screen before focusing on its consumption on digital devices.

These two objectives seek to address a poorly researched and serious problem: women in Spain are widely getting access to work in audiovisual media, but they are still struggling to get access to the most important positions in this type of cultural productions. According to CIMA (the Association of Women Filmmakers and Women in Audiovisual Media), the labour presence of women in Spanish cinema is almost three times lower than that of men: 26\% vs. 74\% (VERTEX, 2017). According to CIMA's President, Virginia Yagüe, the concept of “women's cinema is incorrect” because "women do not make a certain type of cinema", instead they do what the budget allows them to do (BernalTriviño, 2017).

To get access to direct aids from the Cinematography Fund, applicants must conform to the Ministerial requirements of the previous year. The main condition is to manage "a minimum budget of 1.2 million euros" (Bernal-Triviño, 2017). On average, "the films directed by women have budgets of around 800,000 euros, so, in general, the requirement is not met” (Bernal-Triviño, 2017).

Not all directors want their works to be exhibited in cinemas, but we cannot accept the argument that movies directed by women should be limited to a selected audience, which would suggest women should focus on ghetto jobs or niche markets. Cinematographic work seeks and needs the public, even when commercial films are perceived as texts of devalued intellectual quality, in some cases.

The study departs from the principles of cultural studies (Barker, 1994; O’Sullivan, 1997; Grossberg, 2010; Kellner, 2011; Mattelart, 2011), which since the 1970s argued that the mass consumption of products can become a sign of identity for social groups, who re-signify these products and turn them into symbols of cultural resistance (Segarra, Tur \& Del-Pino, 2017; Murciano \& González, 2018; Ortega, Jiménez \& Lavin, 2018).

Thus, the fact that women are not directing films is troubling (Abbot-Tejerina, 2001). One of the goals of feminism is to bring equality to women in all facets of life; including artistic expressions. The main cause of their exclusion from these productions is that filmmaking costs lots of money. To write a novel or a screenplay does not require, virtually, any economic resources while filmmaking and reaching a large audience requires a huge investment.

Women are very excluded from access to the money needed to carry out their projects. They also occupy secondary places in executive positions within the occupational structures of cinema. The way in which this exclusion has occurred in the history of cinema has been studied by various researchers: Núñez-Domínguez, 2010; Núñez-Domínguez, 2012; Zecchi, 2013; Zecchi, 2014; Álvarez, González 
de Garay and Frutos, 2015. These authors have looked at what happened with female directors before and after the development of the powerful machinery of Hollywood cinema, during the second decade of the $20^{\text {th }}$ century. Women went from actively participating in the first film productions to disappearing as directors, producers, directors of photography, and screenwriters. Women's existence was reduced to be actresses or stars created by the advertising system of American cinema, which has been emulated by the industries of Western countries.

Feminist film theory has also demanded a change in the film production structures that reproduce vertical industrial models that favour male authority figures. The EU Framework Programme for Research and Innovation, Horizon 2020, highlights the need to support domestic film, television and publishing industries, while the European Commission has insisted on the limited level of development of the European film industry.

The 2014 report on European Film in the Digital Era. Bridging Cultural Diversity and Competitiveness, pointed out that in Europe has not achieved acceptable levels of audience for the majority of its audiovisual products, in comparison with the North American industry (Commission to the European Parliament, 2014). It explains that the main problem is linguistic diversity, which is an obstacle for the global market.

In the Spanish context, the national film industry has been evaluated (Mollá-Furió, 2011; Lara, 2012; Medina-Nieto, 2018) and possible solutions have been proposed (Castro-Paz 2007; Pérez-Rufí, 2012; Altabás-Fernández, 2014). A commonly observed difficulty is the questionable public management of resources dedicated to cinema, as a subsidised industry (Belinchón, 2015). The law 55/2007 linked grants to box office sales but a year later, with the outbreak of the financial crisis, the grants system collapsed.

To complicate the situation, in 2012 the Government of the People's Party increased taxes on some shows, like cinema and theatre. The value added tax went from $8 \%$ to $21 \%$. Some people saw this increased as acceptable, because they believed that going to the movies was not a basic need. They believed that it is just another product that must compete for the public in a free market of cultural and artistic goods (Spitta, 2013).

This approach contradicts the main idea of Horizon 2020, which says that we must develop and strengthen our cultural industries in a globalised market, and try to set us free from the domain of American businesses on our European cultural productions.

In January 2016, a new law entered into force and established that subsidies should be granted, not based on box office sales, but on the presentation of a project. This change was due to the discovery of box office fraud: gross sales were artificially increased. The law, however, did not change the selection criteria, which favoured the projects of the biggest production companies.

In April of 2018, aids for Spanish film projects amounted to only 30 million euros, which is very low in comparison to France and Italy, where the same aid exceeds, in each country, 350 million euros. Nevertheless, Spain is living a moment of optimism regarding media productions. The Catalogue of Spanish Cinema (Ministry of Education, Culture and Sport, 2017), shows a good pace of releases, although the number of screens per person has decreased. 
Almost all European markets are colonised by the American film industry, composed of large media conglomerates. In the Spanish case, cinemas are controlled by Cinesa, which belongs to the American United Cinema Inc.; Yelmo, owned by Cinépolis-Mexico; and Kinépolis, a Belgian owned company. The Spanish film industry is dominated by foreign capital, across all sectors: production, distribution and exhibition.

In this context, in which an important role is given to the production of cultural goods in the economy of a country, the example of the United Kingdom was very important, as in 2006 its cultural production represented $8 \%$ of the gross domestic product (GDP). The United Kingdom created a model for the European States (Olite-Aldea, 2015), which started to develop a "cultural economy” (Power \& Scott, 2004).

The question is whether relatively small industries, such as Spain, can compete with the big ones, like the United States, India and China. As Martel (2011: 24) has explained, the balance of power in the global sphere is kept by a soft power: "American culture is at the heart of that power of influence, whether it is high or low, art or entertainment, produced at Harvard or Hollywood” (Martel, 2011: 10). Mainstream culture is produced in large clusters of production.

The Statistics Institute of UNESCO (2013) published the report on Emerging markets and the digitisation of the film industry, which pointed out that most films produced in the world are aimed at mass consumption and, above all, at young audiences. Most successful and most-watched movies presented comic characters or were sagas, and were accompanied by large advertising campaigns (UNESCO, 2013).

These blockbusters are an obstacle for the take-off of national industries, given that American productions dominate the lists of top-grossing films worldwide, year after year. Virtually all these movies are distributed by the six major Hollywood studios: CBS Corporation, Comcast Corporation, News Corp., The Walt Disney Company, Time Warner Inc. and Viacom Inc. In this context, how can a small national industry, like the Spanish one, survive? How can women work, in a professional manner, in a highly male-dominated industry, such as cinema? Can male directors appropriately represent women through female characters?

The 2013 report commissioned by Women in Film Los Angeles and Sundance Institute showed that there are more women in American independent cinema than in commercial Hollywood cinema. The report evaluated the presence of women in positions of responsibility, in the films submitted to the Sundance film festival. It found that in these alternative films, women's participation was around 30\%, exceeding the average in commercial movies (Women in Film \& Sundance Institute, 2013). The report also mentions that it was easier for women professionals to get access to documentary film than to fiction, because the latter is more expensive to produce. The report concluded that, in comparison to their male counterparts, women filmmakers tend to give more work to other women behind the camera in positions of responsibility, such as editors and directors of photography.

This research included conclusions on the perception of women regarding their own discrimination in the cinematographic work environment, in which various factors interact: financial barriers associated to gender, with $39.2 \%$; sexist stereotypes in filming sets, with $17.7 \%$; the work-life balance was still a burned on women, with 19.6\%; and discriminatory hiring decisions, with $13.7 \%$. 
Women in Film Los Angeles (2017) expanded and updated the study, with data from 2007 to 2016. According to the results, in the films released during this period, women only represented $4.2 \%$ of the directors, $13.2 \%$ of the screenwriters, $1.7 \%$ of the music composers and $20.7 \%$ of the producers.

In the Spanish film market, women suffer from a situation similar to the United States and the rest of Europe. Progress is really slow (Arranz-Lozano, 2010), although it is not completely stagnated (Martínez-Collado \& Navarrete-Tudela, 2011). However, it is clear that more and more women get access as filmmakers and hopefully also to other positions of responsibility in the film environment, which will improve their representation in the big screen.

\section{Methods}

To achieve the objectives, analyse the detected problems and ensure scientific rigor and validity, we divided the study into three stages of research: 1) the review of primary and secondary sources (books, films and interviews and research articles, databases and reports on international and Spanish cinema); 2) the cataloguing and quantitative and diachronic analysis of the top-grossing Spanish films between 2001 and 2016, (more than ten million euros); and 3) the qualitative and descriptive analysis of these films’ protagonists, plots and stereotypes.

The final sample is composed of 26 of the 100 top-grossing films in the history of Spanish cinema, according to the official report on the "Most-watched and highest-grossing Spanish feature films" commissioned by the Ministry of Education, Culture and Sport of Spain (2017). The analysis of a quarter of the 100 top-grossing films in the history of Spanish cinema guarantees that the sample and the selected units of analysis provide original, valid and effective results.

\section{Results}

Results have been distributed synoptically and in a brief, clear and orderly manner, in two purposecreated tables. The first table includes the selected 26 Spanish films that were produced from 2001 to 2016 and grossed more than ten million euros. For each film, the table includes the directors' name and surname, official revenue in euros and genre:

Table 1: Spanish films that generated over 10 million euros in box office revenues.

\begin{tabular}{|c|c|c|c|c|}
\hline YEAR & TITLE & DIRECTOR & $\begin{array}{l}\text { REVENUE IN } \\
\text { EUROS }\end{array}$ & GENRE \\
\hline 2001 & $\begin{array}{l}\text { 1. Los otros } \\
\text { 2. Torrente 2: Misión en } \\
\text { Marbella }\end{array}$ & $\begin{array}{l}\text { Alejandro Amenábar } \\
\text { Santiago Segura }\end{array}$ & $\begin{array}{l}27.254 .163,38 \\
22.142 .173,13\end{array}$ & $\begin{array}{l}\text { Mystery- } \\
\text { Horror } \\
\text { Comedy }\end{array}$ \\
\hline 2002 & 3. El otro lado de la cama & $\begin{array}{l}\text { Emilio Martínez- } \\
\text { Lázaro }\end{array}$ & 12.616.656,38 & Comedy \\
\hline 2003 & $\begin{array}{l}\text { 4. La gran aventura de } \\
\text { Mortadelo y Filemón } \\
\text { 5. Días de fútbol }\end{array}$ & $\begin{array}{l}\text { Javier Fesser } \\
\text { David Serrano de la } \\
\text { Peña }\end{array}$ & $\begin{array}{l}22.847 .733,13 \\
12.212 .123,98 \\
\end{array}$ & $\begin{array}{l}\text { Comedy } \\
\text { Comedy }\end{array}$ \\
\hline
\end{tabular}




\begin{tabular}{|c|c|c|c|c|}
\hline 2004 & 6. Mar adentro & Alejandro Amenábar & |19.837.472,83 & Drama \\
\hline 2005 & $\begin{array}{l}\text { 7. Torrente 3: El Protector } \\
\text { 8. El reino de los cielos }\end{array}$ & $\begin{array}{l}\text { Santiago Segura } \\
\text { Ridley Scott }\end{array}$ & \begin{tabular}{|l|}
$18.168 .924,78$ \\
$11.984 .458,68$
\end{tabular} & $\begin{array}{l}\text { Comedy } \\
\text { Historical } \\
\text { drama }\end{array}$ \\
\hline 2006 & $\begin{array}{l}\text { 9. Alatriste } \\
\text { 10. Volver }\end{array}$ & $\begin{array}{l}\text { Agustín Díaz Yanes } \\
\text { Pedro Almodóvar }\end{array}$ & $\begin{array}{l}16.715 .741,56 \\
10.243 .096,37\end{array}$ & $\begin{array}{l}\text { Adventure } \\
\text { Drama }\end{array}$ \\
\hline 2007 & 11. El orfanato & Juan Antonio Bayona & $25.061 .449,98$ & $\begin{array}{l}\text { Mystery- } \\
\text { horror }\end{array}$ \\
\hline 2008 & - & - & F & 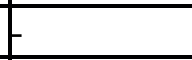 \\
\hline 2009 & $\begin{array}{l}\text { 12. Ágora } \\
\text { 13. Celda } 211 \\
\text { 14. Planet } 51\end{array}$ & $\begin{array}{l}\text { Alejandro Amenábar } \\
\text { Daniel Monzón } \\
\text { Jorge Blanco }\end{array}$ & \begin{tabular}{|l|}
$21.391 .197,61$ \\
$13.145 .423,48$ \\
$11.682 .316,48$
\end{tabular} & $\begin{array}{l}\text { Historical } \\
\text { drama } \\
\text { Police } \\
\text { Children } \\
\end{array}$ \\
\hline 2010 & - & - & F & 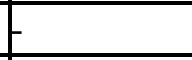 \\
\hline 2011 & 15. Torrente 4: Lethal Crisis & Santiago Segura & $19.356 .588,23$ & Comedy \\
\hline 2012 & $\begin{array}{l}\text { 16. Lo imposible } \\
\text { 17. Las aventuras de Tadeo } \\
\text { Jones } \\
\text { 18. Tengo ganas de ti } \\
\end{array}$ & $\begin{array}{l}\text { Juan Antonio Bayona } \\
\text { Enrique Gato } \\
\text { Fernando González } \\
\text { Molina }\end{array}$ & $\begin{array}{l}42.408 .546,61 \\
18.211 .727,53 \\
12.142 .858,78\end{array}$ & $\begin{array}{l}\text { Drama } \\
\text { Children } \\
\text { Romance }\end{array}$ \\
\hline 2013 & - & - & F & F \\
\hline 2014 & $\begin{array}{l}\text { 19. Ocho apellidos vascos } \\
\text { 20. El niño } \\
\text { 21. Torrente 5: Operación } \\
\text { Eurovegas }\end{array}$ & $\begin{array}{l}\text { Emilio Martínez- } \\
\text { Lázaro } \\
\text { Daniel Monzón } \\
\text { Santiago Segura } \\
\end{array}$ & \begin{tabular}{|l|}
$55.379 .947,62$ \\
$16.206 .693,87$ \\
$10.634 .693,53$
\end{tabular} & $\begin{array}{l}\text { Comedy } \\
\text { Police } \\
\text { Comedy }\end{array}$ \\
\hline 2015 & $\begin{array}{l}\text { 22. Ocho apellidos catalanes } \\
\text { 23. Palmeras en la nieve } \\
\text { 24. Atrapa la bandera } \\
\text { 25. Perdiendo el norte }\end{array}$ & $\begin{array}{l}\text { Emilio Martínez- } \\
\text { Lázaro } \\
\text { Fernando González } \\
\text { Molina } \\
\text { Enrique Gato } \\
\text { Nacho G. Velilla } \\
\end{array}$ & $\begin{array}{l}35.470 .864,94 \\
17.092 .925,42 \\
10.994 .006,33 \\
10.455 .239,92\end{array}$ & $\begin{array}{l}\text { Comedy } \\
\text { Historical } \\
\text { drama } \\
\text { Children } \\
\text { Comedy }\end{array}$ \\
\hline 2016 & 26. Un monstruo viene a verme & Juan Antonio Bayona & $26.030 .151,93$ & Drama \\
\hline
\end{tabular}

Source: Authors' own creation based on data taken from Largometrajes españoles con mayor número de espectadores y con mayor recaudación (Ministerio de Educación Cultura y Deporte, 2017)

As mentioned, this sample represents a quarter of the 100 top-grossing films in the history of Spanish cinema. To find the first women filmmaker, María Ripoll, we have to decrease the revenue range to 10 million. She occupies the $37^{\text {th }}$ position, with the film Ahora o Nunca, which grossed 8,282,836.99 euros and premiered on 19 June 2015. It is a romantic comedy that revolves around the complex preparations wedding for an American-style wedding.

Within these one hundred films there is only another production directed by a woman: Te doy mis ojos, by Icíar Bollaín, which ranked 89, with 5,021,082.70 euros in revenue, and premiered on 24 September, 2003. It was a daring drama that depicts domestic violence within a middle-class marriage. 
Apart from these two movies, there are no films directed or co-directed by a woman in the 100 topgrossing films, nor in the 26 films that grossed over 10 million euros, between 2001 and 2016. During 2008, 2010 and 2013, no Spanish film grossed more than 10 million euros.

The dominant genre is comedy, with ten titles; against seven dramas, three of them are historical; three are children's animated films; two are police-themed movies; two belong to the mystery and horror genre; and one to the romantic and one to the adventure genre.

The following table shows the films' number of male and female characters, ordered by year, and including the name of the actors and actresses. The identification of these characters resulted from the analysis of the films and their official production information in databases, as well as the awards and nominations of the actors and actresses in the leading actor category. In choral films, where all the characters occupy a similar role, we included all names:

Table 2: Male and female protagonists of the Spanish films that grossed over 10 million euros in box office revenue.

\begin{tabular}{|c|c|c|c|}
\hline YEAR & TITLE & $\begin{array}{c}\text { LEADING MALE ACTOR AND } \\
\text { CHARACTER }\end{array}$ & $\begin{array}{l}\text { FEMALE LEAD } \\
\text { ACTRESS AND } \\
\text { CHARACTER }\end{array}$ \\
\hline 2001 & $\begin{array}{l}\text { Los otros } \\
\text { Torrente 2: Misión } \\
\text { en Marbella }\end{array}$ & $\begin{array}{l}\text { - } \\
\text { Santiago Segura (José Luis Torrente). }\end{array}$ & $\begin{array}{l}\text { Nicole Kidman (Grace } \\
\text { Stewart). }\end{array}$ \\
\hline 2002 & $\begin{array}{l}\text { El otro lado de la } \\
\text { cama }\end{array}$ & $\begin{array}{l}\text { Ernesto Alterio (Javier), Willy Toledo } \\
\text { (Pedro), Alberto San Juan (Rafa). }\end{array}$ & $\begin{array}{l}\text { Paz Vega (Sonia), Natalia } \\
\text { Verbeke (Paula). }\end{array}$ \\
\hline 2003 & $\begin{array}{l}\text { La gran aventura de } \\
\text { Mortadelo y } \\
\text { Filemón } \\
\text { Días de fútbol }\end{array}$ & $\begin{array}{l}\text { Pepe Viyuela (Filemón), Benito } \\
\text { Pocino (Mortadelo), Janfri Topera } \\
\text { (Profesor Bacterio). } \\
\text { Ernesto Alterio (Antonio), Alberto } \\
\text { San Juan (Jorge), Fernando Tejero } \\
\text { (Serafín), Roberto Álamo (Ramón). }\end{array}$ & $\begin{array}{l}\text { Natalia Verbeke (Violeta), } \\
\text { Nathalie Poza (Patricia). }\end{array}$ \\
\hline 2004 & Mar adentro & Javier Bardem (Ramón Sampedro). & Belén Rueda (Julia). \\
\hline 2005 & $\begin{array}{l}\text { Torrente 3: El } \\
\text { Protector } \\
\text { El reino de los } \\
\text { cielos }\end{array}$ & $\begin{array}{l}\text { Santiago Segura (José Luis Torrente). } \\
\text { Orlando Bloom (Balian de Ibelin), } \\
\text { Liam Neeson (Godofredo de Ibelin), } \\
\text { Edward Norton (Rey Baldwin). }\end{array}$ & Eva Green (Sibylla). \\
\hline 2006 & $\begin{array}{l}\text { Alatriste } \\
\text { Volver }\end{array}$ & Viggo Mortensen (Diego Alatriste). & $\begin{array}{l}\text { - } \\
\text { Penélope Cruz (Raimunda), } \\
\text { Carmen Maura (Irene). }\end{array}$ \\
\hline 2007 & El orfanato & - & Belén Rueda (Laura). \\
\hline 2008 & - & - & - \\
\hline
\end{tabular}


RLCS, Revista Latina de Comunicación Social, 73 - Pages 1247 to 1266 [Funded] [Research | DOI:10.4185/RLCS-2018-1305en | ISSN 1138-5820 | Year 2018

\begin{tabular}{|c|c|c|c|}
\hline 2009 & $\begin{array}{l}\text { Ágora } \\
\text { Celda } 211 \\
\text { Planet } 51\end{array}$ & $\begin{array}{l}\text { - } \\
\text { Luis Tosar (Malamadre), Alberto } \\
\text { Ammann (Juan Oliver) } \\
\text { Capitán Charles T. Baker (Dwayne } \\
\text { Johnson), General Grawl (Gary } \\
\text { Oldman). }\end{array}$ & $\begin{array}{l}\text { Rachel Weisz (Hipatia de } \\
\text { Alejandría). } \\
\text { - }\end{array}$ \\
\hline 2010 & - & - & - \\
\hline 2011 & $\begin{array}{l}\text { Torrente 4: Lethal } \\
\text { Crisis }\end{array}$ & Santiago Segura (José Luis Torrente). & - \\
\hline 2012 & $\begin{array}{l}\text { Lo imposible } \\
\text { Las aventuras de } \\
\text { Tadeo Jones } \\
\text { Tengo ganas de ti }\end{array}$ & $\begin{array}{l}\text { Ewan McGregor (Henry). } \\
\text { Óscar Barberán (Tadeo Jones). } \\
\text { Mario Casas (Hache). }\end{array}$ & $\begin{array}{l}\text { Naomi Watts (María } \\
\text { Bennett). } \\
\text { Michelle Jenner (Sara). } \\
\text { María Valverde (Babi } \\
\text { Alcázar), Clara Lago (Gin). }\end{array}$ \\
\hline 2013 & - & - & - \\
\hline 2014 & $\begin{array}{l}\text { Ocho apellidos } \\
\text { vascos } \\
\text { El Niño } \\
\text { Torrente 5: } \\
\text { Operación } \\
\text { Eurovegas }\end{array}$ & $\begin{array}{l}\text { Dani Rovira (Rafa), } \\
\text { Karra Elejalde (Koldo). } \\
\text { Luis Tosar (Jesús), Jesús Castro } \\
\text { Romero (Niño) } \\
\text { Santiago Segura (José Luis Torrente). }\end{array}$ & $\begin{array}{l}\text { Clara Lago (Amaia), } \\
\text { Carmen Machi (Merche). } \\
\text { - } \\
\text { - }\end{array}$ \\
\hline 2015 & $\begin{array}{l}\text { Ocho apellidos } \\
\text { catalanes } \\
\text { Palmeras en la niev } \\
\text { Atrapa la bandera } \\
\text { Perdiendo el norte }\end{array}$ & $\begin{array}{l}\text { Dani Rovira (Rafa), } \\
\text { Karra Elejalde (Koldo). } \\
\text { Mario Casas (Killian). } \\
\text { Dani Rovira (Richard Carson). } \\
\text { Yon González (Hugo). }\end{array}$ & $\begin{array}{l}\text { Clara Lago (Amaia), } \\
\text { Carmen Machi (Merche). } \\
\text { Adriana Ugarte (Clarence), } \\
\text { Berta Vázquez (Bisila). } \\
\text { Michelle Jenner (Amy } \\
\text { González). } \\
\text { Blanca Suárez (Carla). }\end{array}$ \\
\hline 2016 & $\begin{array}{l}\text { Un monstruo viene } \\
\text { verme }\end{array}$ & James Melville (Harry) & - \\
\hline
\end{tabular}

Source: Authors' own creation based on data taken from Largometrajes españoles con mayor número de espectadores y con mayor recaudación (Ministerio de Educación Cultura y Deporte, 2017). 
There are 36 male protagonists against 23 female protagonists. When we see these films, in many cases, the feeling is that they are led by a group of characters. However, this group activity revolves around the desires of men, in the majority of cases. This is the case of, for example, Días de fútbol, El reino de los cielos, Celda 211, Ocho apellidos vascos, Ocho apellidos catalanes, Perdiendo el Norte, Tengo ganas de ti, Atrapa la bandera and Las aventuras de Tadeo Jones. The reason for including these last two is that while the narrative revolves around a male character, it presents a group of children who support each other and cooperate to resolve emerging problems.

The great successes of Ocho apellidos vascos and Ocho apellidos catalanes are exemplary in this respect. The plot focuses on a young Andalusian man who wants to seduce a Basque, independent woman away from her cultural principles. The man's friends and the old lady who takes him in as a son, Merche, collaborate to help him get what he wants. In the second part, even his father-in-law, Koldo, goes from being an opponent to a helper in the narrative structure.

We found four times the character of José Luis Torrente, the franchise conceived, directed, produced and starred by Santiago Segura. Torrente is a true anti-hero who reveals what is laughable, ridiculous and frightening. He exaggerates and takes to the limit the so-called privileges of his masculinity. Moreover, he challenges all the principles of good coexistence.

The collected data also indicates that the Spanish public likes film sagas that depict the stereotyped traits of the autonomous communities. While the peoples from these communities are continually parodied and turned into laughing stock, it is interesting to think whether it questions or enhances the sense of unity. In this case, the films of Santiago Segura are also very significant. They are comedy films with huge box-office success that deconstruct what is politically correct, not only in terms of respect among different nationalities, but also among cultures, ethnicities and sexual options. Likewise, women are depicted in a stereotyped manner and, on several occasions, as mere sexual objects.

The parody of nationalities within this diverse Spain is the argumentative plot basis of Ocho apellidos vascos, which is the highest grossing film in the history of Spanish cinema. It outlines the stereotypes of the idiosyncrasy of Basque and Andalusian people. In the second instalment, Ocho apellidos catalanes, the parody focuses on the Catalan nationalist spirit.

Perdiendo el norte also reflects on the current sociological reality of Spain. It uses comedy to deal with one of the main problems of Spanish youth: the difficulty to find work, despite having high qualifications. It is a story of young people forced to immigrate to other countries, where their education is not recognised.

Perdiendo el norte and Tengo ganas de ti address the current problems and experiences of young people, who leave adolescence behind to become independent adults. However, they have a very different character. While the second films tell a story with universalist European background, Perdiendo el norte explores the Spanish sociological reality in a human and friendly manner: highly educated young Spaniards have to emigrate to Germany and survive precariously as previous generations did. 
Beforehand, Días de fútbol and El otro lado also discussed the problems of young adults. The Spanish and European financial situation was different then and the migration of young people to Europe was not the problem, but unemployment and precarious work.

In a more recent time, Perdiendo el norte uses comedy to deal with the tragedy of a country in which educational and development policies have not been able to render the labour market capable of responding to the needs of the modern knowledge economies. It shows the reality of highly qualified young people, in a precarious labour market and an economic system that is more focused on tourism and real estate development; without making gender distinctions.

Apart from that, there are three animated films that have marked the best moment of animation in Spain, despite the last two films are directed by the same person. Las aventuras de Tadeo Jones and Atrapa la bandera are family films that make constant allusions to style of American adventure cinema. In this case, there is no formal reference to Spanish cinema or culture.

\section{Discussion}

The purpose of this research was to look at women in the Spanish commercial cinema, from two perspectives: their professional presence as directors and their representation as characters in the movies. To achieve solid and profound results, we examined a fifteen-year period, from 2001 to 2016, and a sample of 26 movies, dominated by the comedy genre and male protagonists.

With regards to the first objective, we did not find a woman-directed film that had grossed over 10 million euros in the fifteen-year period. In order to find the first female filmmaker, María Ripoll, we had to go down the revenue range to 10 million, to the post $37^{\text {th }}$ in the list of the 100 highest-grossing Spanish commercial films. Behind, there is only another movie directed by a woman, Te doy mis ojos, in the $89^{\text {th }}$ position.

It is difficult to assess the impact of women-directed movies that have reached great successes in other circuits which are not strictly commercial. International recognition has been strong, coming for example from film director Isabel Coixet. She does not appear in the 100 highest-grossing Spanish movies. However, she has managed to introduce several of its movies in international circuits and has received awards and recognitions.

The interest that her work generates, along with other many Spanish women filmmakers, is indisputable and can be confirmed with search of academic articles in databases. Isabel Coixet, Iciar Bollaín, Gracia Querejeta, Helena Taberna and a long list of women filmmakers have found a place in the history of contemporary Spanish cinema (Heredero, 1998; Zecchi, 2013; Zecchi, 2014; Feenstra, 2014; Zurián, 2015). Most of them stand out because their movies are not stereotypical and explore their own narrative language, although some of these movies do not fall far from the commercial pattern.

In relation to the second objective, we see a clear example of the processes of representative inequality. Fraser (1997) would say that the economic disadvantages are added to cultural disrespect. Women filmmakers are real women who have to seek sufficient economic resources to shoot, premiere and distribute their work, and are discriminated against. 
This discrimination is reinforced by the fact that femininity suffers from a deficit of representation in these films. There are more male actors than female ones. The reinforcement mechanisms that exist between sex-based differences can affect negatively the cultural constructions of gender differences. In this regard, there are many interesting research works applied to the press (Galarza, Cobo \& Esquembre, 2016; Núñez, Arenas \& Villar, 2016), childhood (Dávila, Revilla \& Fernández, 2018) and television series (Padilla and Semova, 2009; Padilla, 2010, 2012, 2014).

Fraser (1997) noted the importance of the struggles over the representation of disadvantaged groups and how this fight has characterised the cultural life of postmodernity. Historically disadvantaged groups, both economically and in terms of representation, have worked to gain recognition through the media.

Within these demands, the struggles of women have materialised into claims for equal pay, control over women's body and the right to a dignified public representation. There is a risk that the struggles for women's rights will become trivialised in view of major economic problems of all European States.

If we aspire to full justice, we must think in two dimensions: redistribution and recognition (Fraser, 1997). The concept of redistribution refers to the need to take political decisions to distribute wealth in an equitable manner across the world. Recognition has to do with the right groups, peoples and individuals to be represented fairly in social life. The form of representation can legitimise forms of discrimination.

A study on Spanish commercial cinema and gender-based violence, based on the 20 most commercial films released between 1998 and 2002 (Bernárdez, 2007; Bernárdez, García, \& González, 2008), concluded that commercial cinema tends to not represent physical and structural violence against women in real life. However, if we look at the way women are represented or excluded, there is violence as a form of "social control exerted by the monopoly of representation, of interpretations, and ultimately, symbolic exchanges” (Bernárdez, García \& González, 2008: 49).

How do we put into practice this strategy on audiovisual texts, which are apparently neutral, such as commercial films that, in principle, are based on materials that are liked by everyone?

First, as described in the results section, these films develop a narrative strategy in which individuals want things, led the action and tend to be men. They crave for certain objects and pursue some goals, perform actions, control situations and conquer people emotionally.

Women are companions or aides for the male characters, who must get what they want, launching this way the narrative structures. In comedy, adventure and detective movies, males are who decide what to do: look for an Inca treasure, go to the Moon, get money by selling drugs, arrest offenders, and search for their girlfriends in the Basque Country or Catalonia.

Some women, in supporting roles, also made significant actions for the plot, but almost always these actions have to do with caretaking and mediation, above all, in the family sphere. The character of Merche, Ocho apellidos vascos and Ocho apellidos catalanes is a significant and close example. She has a strong personality, although her role is to help the male protagonists. 
Another example is the mother in Atrapa la bandera. This secondary character becomes the intermediary between the rivalry and resentment between father and son, the protagonists. She ends up becoming the sentimental centre of the plot, even if she has a lower presence in the film.

A remarkable exception is the mother in Lo imposible, a female leading character, whose heroism is associated with her care as a mother. In a similar vein are the female protagonists of Los otros and El orfanato. They are also very strong women. They seem to be excellent mothers. Mothers above all. However, as the plot progresses, their obsession with the perfect maternity leads them to large vital errors and deep psychological problems.

In the male roles, the representation of sentimentality has more antiheros than conventional heroes. Even in a detective movie like El niño, we see how men are able to show their emotions. The problem is not that they do not have feelings, but they are unable to show them or that feelings do not fit into their profession or situation. It is not what is expected of them, in principle. Against this model, we have masculinity exposed with parody, in Santiago Segura's Torrentes. As mentioned, it embodies the most unacceptable and outdated patriarchal values. In this regard, we could relate it to research on other models of masculinity or violent males, as those researched by Caballero-Gálvez \& ZuriánHernández (2016).

The treatment of the comedy of most of the films is also significant. According to the results, comedy predominates compared to other genres. Many of the leading female characters seem to be permanently angry and moody because they do not manage to turn men into what they want. We see this representative strategy in Ocho apellidos vascos and Ocho apellidos catalanes. The main female character appears as someone with more maturity, compared to the other characters; and as a woman with no sense of humour.

They are the most charismatic, almost infantile and gullible, and get empathy with the audience. The secondary character of Merche, the mature woman in terms of age, of Ocho apellidos vascos and Ocho apellidos catalanes is the exception: a sympathetic female character, mostly because it collaborates with men (Trimble, 2014) so that they can achieve their objectives.

The use of violence against women, as a latent element in society, practically does not appear in the analysed movies. It only appears in Volver and Tengo ganas de ti. The latter, and most recent, is a teen romance with a female protagonist represented with equality, with respect to the physical strength of the man with whom she starts a relationship; in the style of the new film heroines who are able to fight and defend themselves (Araüna, 2012).

At one point she is attacked by two men who make her go back to the symbolic place where women belong: an attempt of rape in which she is rescued by her lover. This character embodies the values of a strong heroine. She feels empowered but is also depicted as capricious and arbitrary. When she meets the man who will become her lover, she slaps him almost without justification.

It would respond to the old stereotype of the phallic woman, depicted in film criticism of the 1990s. These women were able to exert physical violence, use weapons, and be aggressive to achieve their goals. In recent years, this model has been adapted to characters who are still feminine, care for others and can be sentimental (Bernárdez, 2012). The term is little acceptable for feminist film criticism, 
since it means recognising that the use of force is the patrimony of males. It serves to check how the stereotype of the woman warrior has been reworked by commercial cinema (McCausland, 2017). It has made it possible for women warriors to also have the qualities typical of female stereotypes, such as taking care of others and acting for reasons that go beyond love tangles.

This stereotype has become naturalised, perhaps as a sociological result of a generation of young people who already feel discriminated against. They have been educated for work and competition and refuse to be recognised as victims. We have already mentioned the example of Tengo ganas de ti, which has a female protagonist who hangs out with a gang of men and stands their jokes and drunkenness. She practices boxing and has a different language and behaviour. All of this empowerment disappears when she is sexually assaulted and is saved by her lover.

There are characters in other films such as Las aventuras de Tadeo Jones, in which conventional roles are reversed: Tadeo is a loser who stumbles before fulfilling his desire of becoming an archaeologist thanks to a series of coincidences. Her friend, Sara, is the strong character, the female Indiana Jones, in its child version, sexualised with her outfit.

She is perfect, but predictable, and collaborates to help Tadeo to become the archaeologist he always wanted to be. It is a curious effect: women are allowed to be active, dominant, practical and effective in their desires, as long as they fit the narrative project of their male companions.

We found another example at the beginning of El niño, embodied in a strong and independent and very talkative police woman. This character becomes diluted in the narrative as the companion of the inspector who solves the case. The secondary character, the Moroccan bride, of the same film, is also interesting in this sense: she is strong, independent, and sells drugs to survive, but settles down and demands stability to her lover in exchange for her love. At the end of the film, she becomes the myth of Penelope: she is able to wait several years for her partner to do his time in jail.

These strong women have a strange point insofar as they incorporate some values of masculinity and, at the same time, are hyper-feminised in their physical form. The question is whether they place real women in front of symbolic forms that really empower them. Our answer is affirmative and positive, in this sense: it is interesting for young women to have cinematographic and cultural models in which they can recognise themselves as strong and independent.

At this point, we believe that this research opens up a line of work that would delve into these new physically strong heroines and hyper-feminised, at the same time. We would be interested to expand the spectrum of super heroines of comics like Marvel Universe and DC, and of female leading characters in conventional films and television series.

The problem is that this phenomenon can be interpreted as an attempt to overcome an inferiority complex: they have to be as men and should develop the same attributes. The feminist interpretation of these figures is reflected Mulvey's classic discourse (1994): women are an erotic show for men. However, we believe that we should not conform to this strict gaze. We are talking about new forms of identity, and more flexible identities in terms of gender construction. 
Another finding is that the representation of sexualities is highly stereotyped. There are practically no conflicts or ambiguities. Heterosexuality is the norm in a universe where there are only homosexual relations. Of course, this point would open another possible line of research.

Cultural diversity is neither the focus of any of the films, although it is in the background to some of them. In our view, the most interesting cases are El niño and Palmeras en la nieve. In the former, there is a love affair between the Spanish protagonist and a Moroccan woman. The conflict is not depicted as intercultural, but as an issue that is resolved at a personal and emotional levels. Lo imposible is also interesting in this sense as its Spanish protagonists suffer the consequences of a tsunami. The Indonesian population is a kind of decoration scenario that increases the drama of the white, Western characters who suffer the tragedy.

Finally, there is an original stereotype that can be explained only in the context of the current crisis: the figure of the mother of Lo imposible. This disaster movie is an example of the dramatisation of the capacity of suffering of mothers over their children. The female protagonist is a bloodied, wounded, bruised mother, a real mater dolorosa, who always thinks of others first, her children and other people's children.

The character of María fits the tradition of the representation of the suffering women. Success may be related to Badinter's (2011: 11) critical idea that motherhood has become the centre of feminine destiny. The tragic heroine, the mater dolorosa, the conflict of the film is not in the family nucleus, but outside of it. María undergoes a transformation throughout the film. She goes from being a womanmother who has given up her career as physician to take care of her children and is thinking about returning to work; to a mother-mother who fights against the effects of a tsunami, in a heroic way, returning to join his family. In this regard, we propose the study of these dichotomies in the representation of a character, as a professional and as a mother.

\section{Conclusions}

Women should be present in all areas of cultural creation in this historic moment in which culture has become an important source of financial resources in developed countries. However, their access to successful film productions is limited by the industry itself. This industry relies more on male directors, when producing the most commercial genres: comedies, dramas, police, animation, adventure.

In Spain, not a single woman has directed a film that has grossed more than 10 million euros. The list of the 100 highest-grossing films in the history of Spanish cinema only includes two female directors: María Ripoll, in the $37^{\text {th }}$ position, and Icíar Bollaín, in the $89^{\text {th }}$. This situation requires the intervention of the public authorities when it comes to cinema subsidies because so far, it rewards box office sales and ignores the public that educate themselves culturally through the consumption of cultural products related to cinema, such as television, music or literature. We will manage to raise the quality of film productions without a public that is educated from institutionalised training centres. So, box office success does not equal quality and the public also receive education in a given sensitivity through the consumption of cultural products.

It is a fact that cinema, even in its stereotyping, has also given visibility to some minorities. It has the possibility of establishing a social dialogue among those who hold a dominant discourse and those 
who represent certain minorities. It shows what everyone thinks and those who challenge the hegemonic sexual, emotional and family models.

The exclusion of women from the production and direction of movies also explains why cinema reinforces the symbolic invisibility in representation. One of the strategies is to avoid female characters who only act as companions or assistants of protagonist male characters who only want to fulfil their desires. In addition, female characters suffer from a deficit of representation because they are frequently depicted as moody and unfriendly; and are attributed the most traditional gender values and roles: caretakers, mothers, fighters.

This situation will not change as long as the representation of women does not change, and this representation will not change as long as there are no new possibilities for women in social life. The intertwining of reality and fiction involves the dimension of gender that we must change to make society fairer for women, in both economic and representative terms. Commercial cinema, as all cultural industries, can contribute positively to building respectful, civil and human citizens; and not mere consumers, who pay a ticket, fill the cinema and respond to the commercial interests of the film industry, without learning a useful message from the films.

* Funded research. This article is the product of a project funded by Santander Bank and the Complutense University of Madrid, titled "Digital gap between teachers and university students: production and cultural consumption through social networks (Facebook, Twitter and Instagram)”, reference PR41/17-20959. Duration: 23/11/2017-23/11/2018, directed by Asunción Bernárdez Rodal, Full Professor at the Complutense University of Madrid.

\section{Dates:}

-Start of research: 8 December 2017.

-End of research: 30 April, 2018.

\section{References}

Abad-Tejerina, M.J. (2001): “¿Para qué sirve el cine comercial en la aldea global? La India un caso singular”. Arte, Individuo y Sociedad, 13, pp. 159 a 170.

\section{http://revistas.ucm.es/index.php/ARIS/article/view/ARIS0101110159A/5911}

Altabás-Fernández, C. (2014): “Autofinanciación y crowdfunding: Nuevas vías de producción, distribución y exhibición del cine español independiente tras la crisis financiera española”. Historia y Comunicación Social, 19, pp. 387 a 399.

http://revistas.ucm.es/index.php/HICS/article/view/45141/42504 DOI: http://dx.doi.org/10.5209/rev_HICS.2014.v19.45141

Álvarez-Hernández, C., González de Garay-Domínguez, B. \& Frutos-Esteban, F.J. (2015):

“Representación de género. Las películas españolas contemporáneas de adolescentes (2009-2014)”. 
Revista Latina de Comunicación Social, 70, pp. 934 a 960.

http://www.revistalatinacs.org/070/paper/1079/49es.html DOI: 10.4185/RLCS-2015-1079

Araüna, N. (2012): “Gender violence and the representation of sexual and affective relationships: Reflections on cross-media research”. Catalan Journal of Communication \& Cultural Studies, 4(2), pp. 239 a 248.

http://www.ingentaconnect.com/contentone/intellect/cjcs/2012/00000004/00000002/art00007?crawle r=true DOI: https://doi.org/10.1386/cjcs.4.2.239_1

Arranz-Lozano, F. (Ed.) (2010): Cine y género en España: Una investigación empírica. Madrid: Cátedra.

Badinter, E. (2011): La mujer y la madre: un libro polémico sobre la maternidad como nueva forma de esclavitud. Madrid: La Esfera de Libros.

Barker, M. (1994): Introducción a los estudios culturales. Barcelona: Bosch.

Belinchón, B. (2015): “Historia de una subvención. Un repaso a las diversas leyes del Cine que han regulado las ayudas a la producción de películas durante de la democracia”. El País, 24 November, Spain: https://elpais.com/cultura/2015/11/23/actualidad/1448293938_944030.html (8 de abril de 2018).

Bernal-Triviño, A.I. (2017): “El techo de cristal de las mujeres en el cine español”. Público, 29 de marzo, España: http://www.publico.es/culturas/techo-cristal-mujeres-cine-espanol.html (8 April 2018).

Bernárdez-Rodal, A. (2007): “Representaciones cinematográficas de la violencia de género: Femenino y masculino en el cine comercial español”. Circunstancia, 12, pp. 1-12.

Bernárdez-Rodal, A. (2012): “Modelos de mujeres fálicas del postfeminismo mediático: Una aproximación a Millenium, Avatar y Los juegos del hambre”. Anàlisi, 47, pp. 91 a 112.

Bernárdez, A., García, I. \& González, S. (2008): Violencia de género en el cine español: Análisis de los años 1998 a 2002 y guía didáctica. Madrid: Editorial Complutense.

Caballero-Gálvez, A.A. \& Zurián-Hernández, F.A. (2016): “Machos violentos y peligrosos. La figura del maltratador en el cine almodovariano". Revista Latina de Comunicación Social, 71, pp. 853-873. http://www.revistalatinacs.org/071/paper/1124/44es.html DOI: 10.4185/RLCS-2016-1124

Castro-Paz, J.L. (2007): “La encrucijada de la historia del cine español”. Comunicar, 15(29), pp. 3945. https://www.revistacomunicar.com/index.php?contenido=detalles\&numero=29\&articulo=29$\underline{2007-07}$

CIMA (Asociación de Mujeres Cineastas y Medios Audiovisuales) (2017): Informe CIMA 2016. La representatividad de las mujeres en el sector cinematográfico español. Madrid, España: CIMA. https://cimamujerescineastas.es/wp-content/uploads/2018/01/INFORME-FINAL-ESTUDIO2016.pdf (8 April 2018). 
Commission to the European Parliament (2014): "European film in the digital era. Bridging cultural diversity and competitiveness”. Brussels, Belgium: European Parliament. https://eurlex.europa.eu/legal-content/EN/TXT/?uri=celex\%3A52014DC0272 (8 April 2018).

Dávila-de-León, M.C., Revilla-Castro, J.C. \& Fernández-Villanueva, C. (2018): “Más allá de la mera exposición: Violencia en televisión en horario protegido”. Revista Latina de Comunicación Social, 73, pp. 352-368.

http://www.revistalatinacs.org/073paper/1259/18es.html

DOI: $10.4185 / R L C S-2018-1259$

Feenstra, P. (2014): Directoras de cine en España y América latina: Nuevas voces y miradas. Frankfurt: Peter Lang.

Fraser, N. (1997): Iustitia interrupta: reflexiones críticas desde la posición postcolonialista. Santa Fe de Bogotá: Siglo del Hombre Editores.

Galarza-Fernández, E., Cobo-Bedía, R. \& Esquembre Cerdá, M. (2016): “Medios y violencia simbólica contra las mujeres”. Revista Latina de Comunicación Social, 71, pp. 818-832. http://www.revistalatinacs.org/071/paper/1122/42es.html DOI: 10.4185/RLCS-2016-1122

Grossberg, L. (2010): Estudios culturales: Teoría, política y práctica. Valencia: Letra Capital.

Heredero, C.F. (1998): La mitad del cielo: Directoras españolas de los años 90. Málaga: Primer Festival de Cine Español de Málaga.

Kellner, D. (2011): Cultura mediática: Estudios culturales, identidad y política entre lo moderno y lo posmoderno. Madrid: Akal.

Lara, F. (2012): Cine español. El estado de la cuestión. Madrid: Academia del Cine.

Martínez-Collado, A. \& Navarrete-Tudela, A. (2011): “Mujeres e (industria) audiovisual hoy: Involución, experimentación y nuevos modelos narrativos”. Tesi, 12(1), pp. 8-23.

Mattelart, A. (2011): Introducción a los estudios culturales. Barcelona: Paidós.

McCausland, E. (2017): Wonderwoman. El feminismo como superpoder. Madrid: Errata Naturae.

Medina-Nieto, M. (2018): “Análisis crítico de la producción de contenidos y de la ley de la radio y la televisión de titularidad estatal. El caso de TVE”. Revista Latina de Comunicación Social, 73, pp. 730-747.

http://www.revistalatinacs.org/073paper/1279/38es.html DOI: 10.4185/RLCS-2018-1279

Ministerio de Educación, Cultura y Deporte (2017): Catálogo del Cine Español. Madrid, España: Ministerio de Educación, Cultura y Deporte.

http://www.mecd.gob.es/catalogodecine/2015/presentacion.html (8 April 2018). 
Ministerio de Educación, Cultura y Deporte (2017): Largometrajes españoles con mayor número de espectadores y con mayor recaudación. Madrid, España: Ministerio de Educación, Cultura y Deporte.

http://www.mecd.gob.es/dam/jcr:bbb653ce-d129-43dc-9d9e-c2d911626c87/33-largos-esp-recesp.pdf (8 April 2018).

Mollá-Furió, D. (2011): “Cine, mercado y publicidad: La industria cinematográfica española y los nuevos modelos de producción”, in Actas del IV Congreso Internacional sobre análisis fílmico, nuevas tendencias e hibridaciones de los discursos audiovisuales en la cultura digital contemporánea (Coord. Por I. Bort, I. García \& S. Marta). Madrid: Ediciones de las Ciencias Sociales.

Mulvey, L. (1994): Placer visual y cine narrativo. Miami: Episteme.

Murciano-Martínez, M. \& González-Saavedra, C. (2018): "Las industrias culturales y creativas en las comunidades autónomas españolas: El caso Cataluña”. Revista Latina de Comunicación Social, 73, pp. 146-167.

http://www.revistalatinacs.org/073paper/1250/09es.html

DOI: $10.4185 / R L C S-2018-1250$

Núñez-Domínguez, T. (2010): “Mujeres directoras de cine: Un reto, una esperanza”. Pixel-Bit. Revista De Medios y Educación, 37, pp. 121 a 133.

Núñez Domínguez, T. (2012): Directoras de cine español: Ayer, hoy y mañana, mostrando talentos. Sevilla: Fundación Audiovisual de Andalucía y Universidad de Sevilla.

Ortega-Mohedano, F., Jiménez-Sánchez, A. \& Lavín, J.M. (2018): “Industrias culturales y composición de los personajes en las series de animación infantil emitidas en España”. Revista Latina de Comunicación Social, 73, pp. 74 a 88.

http://www.revistalatinacs.org/073paper/1246/05es.html

DOI: $10.4185 /$ RLCS-2018-1246

O’Sullivan, T. (1997): Conceptos clave en comunicación y estudios culturales. Buenos Aires: Amorrortu.

Padilla-Castillo, G. \& Semova, D.J. (2009): Los juegos de las series favoritas de los universitarios madrileños. CIC: Cuadernos de información y comunicación, 14, pp. 199-211.

Padilla-Castillo, G. (2010): “Los antihéroes televisivos desde las perspectivas del Análisis Transaccional, la Ética, la Moral y la Política”. Revista de análisis transaccional y psicología humanista, 62, pp. 81-101.

Padilla-Castillo, G. (2012): “Las series de televisión sobre médicos como ejemplo de enseñanza en nutrición y gastronomía”. Revista Latina de Comunicación Social, 67, pp. 229 a 247. http://www.revistalatinacs.org/067/art/954_Complutense/10_Graciela.html DOI: 10.4185/RLCS067-954-229-247 / CrossRef link 
Padilla-Castillo, G. (2014): “Teoría de la información y de la comunicación en una serie de televisión: Scandal”. Historia y comunicación social, 19(2), pp. 133-144.

Pérez-Rufí, J. (2012): “La tormenta perfecta del cine español: situación de la industria cinematográfica en España”. Razón y Palabra, 81, pp. 1-32.

http://www.razonypalabra.org.mx/N/N81/V81/30_Perez_V81.pdf

Power, D. \& Scott, A.J. (2004): Cultural Industries and The Production of Cultura. New York: Routledge.

Spitta, S. (2013): “Hispanic cinema and the aesthetics of deceleration: Festival report”. Studies in Spanish \& Latin American Cinemas, 10(2), pp. 225-234.

http://www.ingentaconnect.com/content/intellect/sslac/2013/00000010/00000002/art00008 DOI: https://doi.org/10.1386/slac.10.2.225_7

Trimble, L. (2014): “Melodrama and gendered mediation”. Feminist Media Studies, 14(4), pp. 663678. https://www.tandfonline.com/doi/abs/10.1080/14680777.2013.826268?journalCode=rfms20 DOI: https://doi.org/10.1080/14680777.2013.826268

UNESCO (2013): Mercados emergentes y la digitalización de la industria cinematográfica: análisis de la encuesta internacional del UIS del año 2012 sobre las estadísticas de largometrajes. Nueva York: UNESDOC. http://unesdoc.unesco.org/Ulis/cgi-bin/ulis.pl?catno=227279\&gp=\&lin=1\&ll=f (8 April 2018).

Zecchi, B. (Coord.) (2013): Gynocine: Teoría de género, filmología y praxis cinematográfica. Zaragoza: Amherst.

Zecchi, B. (2014): Desenfocadas: Cineastas españolas y discursos de género. Barcelona: Prensa de la Universidad de Zaragoza.

Zurián, F.A. (Coord.) (2015): Construyendo su propia mirada. Mujeres directoras en el cine español. Madrid: Síntesis.

Women in Film \& Sundance Institute (2013): Inequality for female directors. Los Angeles, Estados Unidos: Women in Film. https://womeninfilm.org/ffi/ (8 April 2018).

Women in Film Los Angeles (2017): Women across popular films from 2007-2016. Los Angeles, Estados Unidos: Women in Film. https://womeninfilm.org/ (8 April 2018).

\section{Related articles}

Cáceres, M.D. (2008): "El cuerpo deseado y el cuerpo vivido. La apropiación de los discursos mediáticos y la identidad de género”. CIC Cuadernos de Información y Comunicación, 13, pp. 195214. http://revistas.ucm.es/index.php/CIYC/article/view/CIYC0808110195A/7246

Lacalle, Ch. \& Castro, D. (2018): "Fandom televisivo y construcción de identidad. Análisis de los comentarios de las fans españolas y los community managers”. Revista Latina de Comunicación 
Social, 73, pp. 1-18. http://www.revistalatinacs.org/073paper/1242/01es.html DOI: 10.4185/RLCS2018-1242

Gamboa, J. (2001): “La mujer, en los talk shows”. Revista Latina de Comunicación Social, no 42. http://www.revistalatinacs.org/2001/latina42jun/41gamboa.htm

García, A. \& Piñeiro, T. (2011): “Las mujeres en el ámbito de la producción publicitaria. Estudio del sector publicitario gallego desde una perspectiva de género”. Revista Latina de Comunicación Social, 66, pp. 505-525. http://www.revistalatinacs.org/11/art/943_Galicia/22_Aurora.html DOI: 10.4185/RLCS-66-2011-943-505-525.

Núñez-Domínguez, T., Arenas-Molina, M.T. \& Villar, M.E. (2016): “¿Cómo se ven? ¿Cómo las ven? Discriminar en la construcción”. Revista Latina de Comunicación Social, 71, pp. 976-993. http://www.revistalatinacs.org/071/paper/1130/50es.html DOI: 10.4185/RLCS-2016-1130

Padilla-Castillo, G. (2009): "El éxito de Mujeres desesperadas desde el análisis transaccional”. Revista de Análisis Transaccional y Psicología Humanista, 60, pp. 20-35.

How to cite this article in bibliographies / References

A Bernárdez-Rodal, G Padilla-Castillo (2018): “Female filmmakers and women’s representation in Spanish commercial cinema (2001-2016)”. Revista Latina de Comunicación Social, 73, pp. 1247 a 1266.

http://www.revistalatinacs.org/073paper/1305/64en.html

DOI: 10.4185/RLCS-2018-1305en

Article received on 22 May 2018. Accepted on 27 June. Published on 6 July 2018. 